\title{
OPEN Global carbon sequestration through continental chemical weathering in a climatic change context
}

\begin{abstract}
Juan Luis Lechuga-Crespo ${ }^{1,2}$, Sabine Sauvage ${ }^{2}$, Estilita Ruiz-Romera ${ }^{1}$, Michelle T. H. van Vliet ${ }^{3}$, Jean-Luc Probst ${ }^{2}$, Clément Fabre ${ }^{4}$ \& José Miguel Sánchez-Pérez ${ }^{2 凶}$

This study simulates carbon dioxide $\left(\mathrm{CO}_{2}\right)$ sequestration in 300 major world river basins (about $70 \%$ of global surface area) through carbonates dissolution and silicate hydrolysis. For each river basin, the daily timescale impacts under the RCP 2.6 and RCP 8.5 climate scenarios were assessed relative to a historical baseline (1969-1999) using a cascade of models accounting for the hydrological evolution under climate change scenarios. Here we show that the global temporal evolution of the $\mathrm{CO}_{2}$ uptake presents a general increase in the annual amount of $\mathrm{CO}_{2}$ consumed from $0.247 \pm 0.045 \mathrm{PgC}$ year $^{-1}$ to 0.261 and $0.273 \pm 0.054 \mathrm{PgC}$ year $^{-1}$, respectively for RCP 2.6 and RCP 8.5. Despite showing a general increase in the global daily carbon sequestration, both climate scenarios show a decrease between June and August. Such projected changes have been mapped and evaluated against changes in hydrology, identifying hot spots and moments for the annual and seasonal periods.
\end{abstract}

Chemical weathering of rocks has a significant impact on long-term global climate regulation ${ }^{1}$. It transforms soil $\mathrm{CO}_{2}$ into inorganic dissolved carbon (such as $\mathrm{HCO}_{3}{ }^{-}$and $\mathrm{CO}_{3}{ }^{2-}$ ), which is later exported by rivers to other water bodies $^{2-11}$. Riverine dissolved loadings may be used as a proxy for chemical weathering assessment ${ }^{4,11}$, and it has been recognised that hydrology impacts these flux-discharge relationships ${ }^{5-7}$. Nevertheless, it is unclear how the potential impacts of climate change will affect these dissolved mass balances. Forecasting how potential shortterm (daily or monthly) shifts in hydrology under a changing climate may alter these fluxes of riverine matter is needed to assess the potential evolution of the global carbon cycle under a wide range of future scenarios. Here we hypothesized that a more significant seasonality of the hydrological cycle would cause a heterogeneous spatial and temporal pattern in $\mathrm{CO}_{2}$ sequestration at the global scale.

Climate change scenarios show increases in air temperatures and significant changes in the hydrological cycle ${ }^{12}$. Still, its effect on chemical weathering and related $\mathrm{CO}_{2}$ uptake dynamics and dissolved solids exportation by rivers is poorly understood ${ }^{13}$. For instance, on one side, an increase in the soils microbial activity is expected, implying an increase in $\mathrm{CO}_{2}$ production through respiration ${ }^{14,15}$. However, higher air temperatures may decrease $\mathrm{CO}_{2}$ dissolution in water, as carbonate weathering follows a boomerang-shaped evolution with increasing temperature ${ }^{16}$. Hydrology is the dominant driver of matter transport at large scale ${ }^{17}$. Nevertheless, the potential implication of respiration and temperature in the global balance remains poorly understood ${ }^{13}$.

How will the annual soil $\mathrm{CO}_{2}$ consumption evolve under these hydrological shifts? Where and when will these soil $\mathrm{CO}_{2}$ consumption changes be more relevant? The answer to these scientific questions needs a largescale comprehensive field study. However, such a study is challenging regarding the in situ resources needed to measure the variables involved in these biogeochemical cycles.

In this complex framework, modelling arises as an alternative approach to overcome this challenge by yielding insights into where and when hot spots and hot moments (places and times with disproportionally high chemical weathering rates) may be located. Identifying potential hot spots and moments of change is important to target areas needing the deployment of resources to understand in situ processes, which could yield relevant 
a

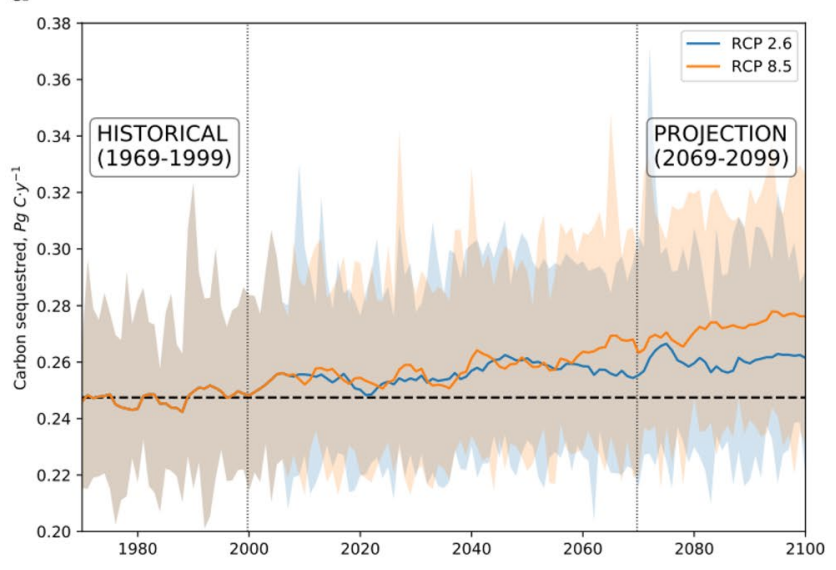

b

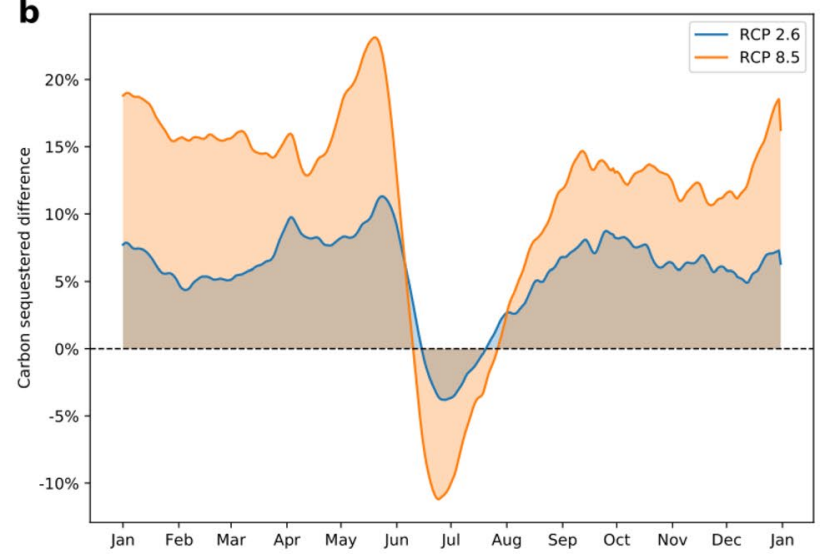

Figure 1. Temporal evolution of the global soil $\mathrm{CO}_{2}$ sequestered for the RCP 2.6 (blue) and RCP 8.5 (orange) scenario: (a) interannual fluctuations in annual weathering $\mathrm{CO}_{2}$ consumption, where shaded areas represent the minimum and maximum amount of annual carbon sequestered in five general circulation models, and the solid lines account for a 10-year moving average to evaluate the pattern. The dashed horizontal line represents the mean consumption for the Historical period. (b) Seasonal variations for the daily mean relative difference between the Projection (ECP) and Historical periods.

insights for landscape biogeochemistry. Two main types of models exist for our approach: mechanistic models if processes are constrained by basic physical principles, such as thermodynamic laws and conservation of mass, and empirical models when built using parametric relationships derived from observational data. Mechanistic models, such as B-WITCH ${ }^{15,18}$ and RT-Flux-PIHM ${ }^{19,20}$, link thermodynamics, kinetics and transport processes to hydrology and vegetation. They have yielded insights, for instance, that $40 \%$ of the total increase in $\mathrm{CO}_{2}$ consumption in the Mackenzie River basin is related to the direct effect of climate change on hydrology alteration ${ }^{15}$. Moreover, they highlighted that a "chemostatic" behaviour of riverine dissolved load suggests that hydrological changes impact the dissolved element concentration in rivers ${ }^{19,20}$. Empirical models are commonly developed at large spatial scales ${ }^{7,21}$, and their results are used in relevant assessments such as the ESCOBA program ${ }^{22}$ and the IPCC Assessment Reports ${ }^{12}$.

The objective of this study was to assess the impact of future modifications of the hydrological cycle on the global $\mathrm{CO}_{2}$ sequestration by weathering. Based on the largest basins in the world, we aimed at identifying the watersheds or areas with higher $\mathrm{CO}_{2}$ consumption compared to the rest of the globe (hot spots ${ }^{23}$ ) and the periods showing larger sequestration (hot moments ${ }^{23}$ ) on which to focus research efforts.

In this study, a cascade of models was set up to cover the 300 largest basins in the world, obtaining the spatial and temporal potential evolution of $\mathrm{CO}_{2}$ sequestration under two climate change scenarios (RCP 2.6 and RCP 8.5). Historical and future dynamics of cations and anions derived from chemical weathering of rocks and associated carbon sequestration were modelled by coupling the hydrological model VIC with the geochemical model ICWR. Then, the results from this set-up were used as an input in the MEGA model to estimate $\mathrm{CO}_{2}$ consumption. Observed data have been used to evaluate the results at each step of the model cascade. The reader is referred to the methods section and the Extended Data Fig. 2.

\section{Results and discussion}

Interannual and seasonal fluctuations. The annual mean inorganic $\mathrm{C}$ sequestration through chemical weathering during the Historical period (1969-1999) amounts to $0.247 \mathrm{Pg} \mathrm{C}_{\text {year }}{ }^{-1}\left(1 \mathrm{Pg}=10^{15} \mathrm{~g}\right)$, in the lower range of previous research ${ }^{4,8-11,21,24-27}$, spanning from 0.22 to $0.30 \mathrm{Pg} \mathrm{C}$ year $^{-1}$. The climate change scenarios present a potential increase in the amount of $\mathrm{C}$ sequestered, reaching mean values of 0.261 and $0.273 \mathrm{Pg} \mathrm{C}$ year $^{-1}$ for RCP 2.6 and RCP 8.5, respectively. The annual series (Fig. 1a) shows a similar temporal evolution for the middle part of the century, but such a difference enlarges within the "End of Century Projection" (ECP) period (2069-2099). An annual average increase in C sequestration of 6\% (RCP 2.6) and 10\% (RCP 8.5) is forecasted if the Historical period is considered the baseline. The annual increases represent $<0.1 \%$ of the anthropogenic emissions projected for 2100 in the RCP 8.5 scenario and $\sim 0.7 \%$ of the "negative emissions" projected for the RCP2.6 scenario ${ }^{28}$. These $C$ sequestration increases are low at the global scale; however, these become more relevant when evaluating the change percentages at a lower time-step (daily).

When comparing the mean daily temporal evolution in the ECP and the Historical periods (Fig. 1b), more considerable differences are found for the RCP 8.5 scenario. In both scenarios, a positive difference is found for most of the year, agreeing with a more considerable amount of $\mathrm{C}$ sequestered during the ECP period compared to the Historical one. Such increases may reach a positive $20 \%$ value in May for the RCP 8.5 scenario, followed by a shift towards a decrease between June and August. It suggests a lower $\mathrm{CO}_{2}$ consumption through continental chemical weathering during these months. Previous studies highlighted that hydrology is a dominant driver in the temporal evolution of $\mathrm{CO}_{2}$ consumption ${ }^{29}$. Therefore, a decrease in $\mathrm{CO}_{2}$ consumption suggests that a lower amount of water is being exported in this period. This decrease coincides with the low discharge period in the 


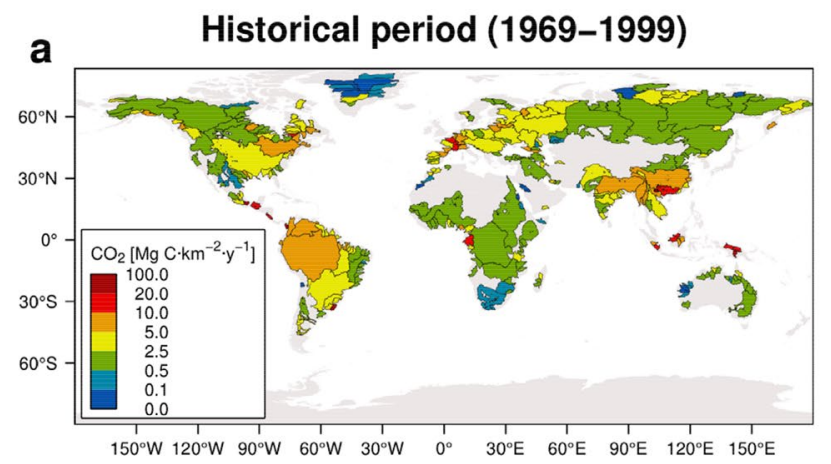

Projection period (2069-2099)
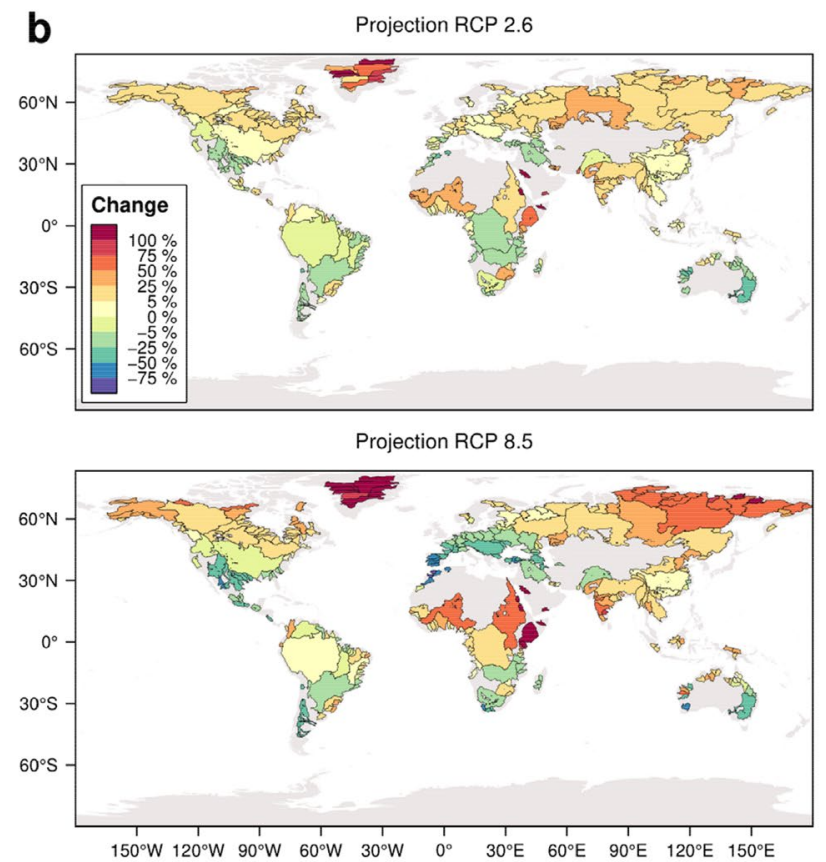

Figure 2. (a) Interannual mean $\mathrm{CO}_{2}$ consumption through chemical weathering during the Historical period, expressed as $\mathrm{Mg} \mathrm{C}$ year-1 $\mathrm{km}^{-2}$; and (b) relative change for the Projection (ECP) period in the RCP 2.6 and RCP 8.5 climate scenarios, expressed as a percentage of change regarding the Historical period. The maps were created with the R software (version 4.0.3; https://www.r-project.org/).

northern latitudes, suggesting that these regions significantly influence the global amount of soil $\mathrm{CO}_{2}$ consumed through chemical weathering. The Northern Hemisphere has a more considerable amount of continental land and the hydrological cycle is expected to intensify in these areas. This suggests that the annual shift found between June and August regarding the global carbon weathering $\mathrm{CO}_{2}$ uptake could be a consequence of hydrological changes at these latitudes.

Hot spots and moments for $\mathrm{CO}_{2}$ uptake. On a global scale, the spatial distribution of carbon sequestration during the Historical period (Fig. 2a) is comparable to what is described in previous literature ${ }^{7}$. Similarly, values are analogous to regional cases, such as the Amazon ${ }^{11,29,30}$, Congo $^{5,21}$, Niger $^{31}$, Garonne ${ }^{21}$, the Alps region $^{32}$ or the United States continuum ${ }^{33}$, even if the lateritic soils have lower $\mathrm{CO}_{2}$ uptake, as shown by Boeglin \& Probst $^{31}$.

Alterations in this spatial pattern (Fig. 2b) are considered primary consequences of hydrological changes since the geochemical processes take place over a much larger time scale than biogeochemical processes on the Earth surface. More significant changes are found in the northern latitudes, where an increase in the annual discharges in these river basins is expected due to a larger precipitation amount, an earlier onset and a more intensive snowmelt in spring ${ }^{34}$. Even though a higher seasonality will change the hydrological cycle within the year.

A general increasing trend in $\mathrm{CO}_{2}$ sequestration is found during the January-February-March (JFM) period (Extended Data Fig. 1), especially in basins such as the Yenisei and the Ob, which present changes $>25 \%$, particularly in the RCP 8.5 scenario. Increasing temperatures are expected to cause an accelerated snowmelt ${ }^{34}$, which could lead to the increase of dissolved inorganic carbon river fluxes. In contrast, heterogeneous projections are 


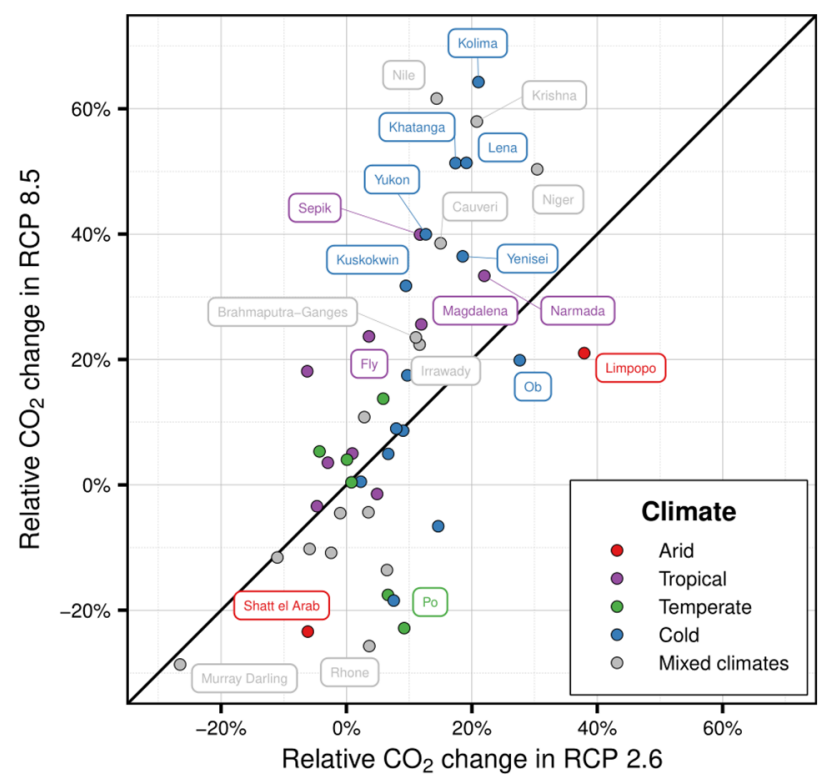

Figure 3. Comparison of the relative $\mathrm{CO}_{2}$ uptake change in the river basins used for MEGA ${ }^{21}$ model validation for both climatic scenarios. Only river basins showing a relative change over $\pm 20 \%$ are labelled. The straight black line represents equal change.

found for southern latitudes, as in the Murray-Darling River basin in Australia and the Orange River in South Africa. These basins are located under mixed climatic zones ${ }^{35}$, which could explain the heterogeneous results found in the scenarios. The potential evolution in the river discharge seasonality in these areas may cause different geochemical fluxes since a discharge decrease of more than $25 \%$ in the low-flow period is expected ${ }^{34}$. However, further analysis using mechanistic approaches or in situ measurements is needed to understand and assess potential changes in biogeochemical cycles in these regions during the January to March (JFM) period.

A different pattern is found for the July-August-September (JAS) season, when most of the northern latitudes present negative changes, suggesting a decrease in the $\mathrm{CO}_{2}$ uptake due to chemical weathering. This shift in the northern latitudes is attributed to a projected decline in discharge, notably on the RCP 8.5 scenario $^{36}$.

As discharge intensity is a primary critical factor of $\mathrm{CO}_{2}$ flux changes in the short-term (daily, monthly or seasonal) assessment, we compared the relative changes in $\mathrm{CO}_{2}$ uptake in a subset of river basins for both scenarios (Fig. 3). Such a comparison illustrates how watersheds located in tropical and cold climates present significant differences for $\mathrm{CO}_{2}$ uptake, especially basins in the Siberian region (e.g. Kolyma, Khatanga or Lena) or active arc-islands in New Guinea (e.g. Fly or Sepik). These changes show that, even with their smaller draining areas and discharges, the role of arc-islands should be taken into consideration and should be a focus of future research as their relative role in carbon sequestration through chemical weathering is relevant ${ }^{7}$. Besides, the potential impacts of climate change in these tropical areas are expected to be more relevant in these smaller river basins than in larger ones like the Amazon or Congo ${ }^{7}$.

Similarly, the relative change in $\mathrm{CO}_{2}$ sequestration on watersheds with mixed climates (e.g. the Nile, Krishna, Niger or Murray Darling) is large. It could be related to higher amounts of carbonate rock outcrops in these areas, releasing significant amounts of $\mathrm{CO}_{2}$ during weathering ${ }^{37}$. Regarding cold and polar basins, permafrost processes were not included in the present analysis. They are expected to significantly impact the carbon sequestration by weathering and the loads to rivers ${ }^{38}$.

Even though there are some relative changes noted at the annual scale, these differences are not maintained throughout the year. The short-term temporal evolution should be a focus of interest for future research, especially in those areas located in tropical and cold climates since they seem to be more sensitive to climate change.

Modelling approach limitations. This study uses a model output as input to another model, which implies a propagation of the error in each step. We assessed the uncertainties of our approach with previously published data. The results show a very significant correlation to observed data ${ }^{27}$ for the ICWR model $\left(\rho_{\text {SPEARMAN }}=0.83\right.$, $\mathrm{p}<0.01, \mathrm{n}=173$, see Extended Data Fig. 5), as well as for the MEGA model results in the Historical period ${ }^{6}$ $\left(\rho_{\text {SPEARMAN }}=0.71, \mathrm{p}<0.01, \mathrm{n}=48\right.$, see Extended Data Fig. 6 ). In summary, even though a cascade of models usually accumulates errors, the present modelling approach fits well with current observed data.

Continental weathering occurs at the critical zone, where slow geological processes interact with faster biogeochemical ones. The present modelling approach includes a macroscale hydrological model, which resolves the energy and water balance. The main uncertainties are discussed elsewhere ${ }^{36}$. Concerning the ICWR model, the parameters have been fitted to observed data for a given situation. These laws may change under a climate change scenario. The MEGA model balance is based on a set of hypotheses described in the literature and summarised in the Extended Data Fig. 4. The main limitation of this modelling set-up is that it does not simulate transient states, as the chemical weathering rates are described through linear equations. Regolith thickness is 
kept constant during simulation even though it is coupled to physical erosion, which could change chemical weathering rates ${ }^{39}$. Temporal variation of below-ground $\mathrm{CO}_{2}$ concentration is not included in the ICWR model, even though it has been noted as relevant in silicate weathering and affected by vegetation changes ${ }^{40}$. Further uncertainties are related to the resolution of the lithological map (see "Methods" section). It has already been shown that using a map with a finer resolution helped improve the modelling results at local scale ${ }^{41}$.

\section{Conclusion}

This study presents a forecast of the potential evolution of $\mathrm{CO}_{2}$ consumption during the chemical weathering of continental rocks at the global scale under two climate change scenarios. The research provides two main new insights on the temporal evolution of the carbon cycle in the short-term, derived from shifts in the water cycle: (a) Even though there is a trend towards increasing the amount of carbon sequestered at the annual and global scale, this pattern is not homogeneously distributed neither in space nor time, and (b) the river basins located in cold climates (such as the Kolyma, Lena, Yukon, Kuskokwim or Yenisei) and in tropical climates with a lower draining area (like the Fly, Sepik or Narmada) may be more sensitive to the effects of climate change.

The insights presented suggest that research on the terrestrial part of the carbon cycle should focus on these areas to constrain the main cycle-shaping drivers better, targeting an understanding of the carbon fluxes' temporal dynamics. This study provides the first snapshot of carbon sequestration's potential evolution through the chemical weathering of rocks on a global scale, which may be used for comparison in future studies in this field. Even if the carbon fluxes from chemical weathering are small compared to the total $\mathrm{CO} 2$ emissions, they are in the same order of magnitude with the natural CO2 emissions to the atmosphere. Local increases in chemical weathering could lead to acidification of local surface waters, which could affect the equilibrium of freshwater and coastal ecosystems.

\section{Methods}

Four Representative Concentration Pathways (RCP) were selected by the Intergovernmental Panel on Climate Change (IPCC) in its fifth Assessment Report ${ }^{12}$ regarding climate change impacts on the carbon cycle. Two of those four RCPs are included in the present analysis (RCP 2.6 and RCP 8.5). RCP 2.6 considers that the radiative forcing (i.e. the strength of change drivers) will peak at about $2.6 \mathrm{~W} \mathrm{~m}^{-2}$ in 2100 and then decline, whereas RCP 8.5 considers that the radiative forcing will reach $>8.5 \mathrm{~W} \mathrm{~m}^{-2}$ by 2100 . The highest and lowest RCPs were selected to capture the broadest range of future expected atmospheric greenhouse gas concentrations. Biascorrected climate model outputs of five general circulation models (GCM) were included in the VIC hydrological model to simulate impacts on daily river discharge on $0.5^{\circ} \times 0.5^{\circ}$ at the global scale ${ }^{36}$ : GFDL-ESM2M ${ }^{42,43}$, HadGEM2-ES ${ }^{44,45}$, IPSL-CM5A-LR ${ }^{46}$, MIROC-ESM-CHEM ${ }^{47}$, and NorESM1-M ${ }^{48}$. Validation results showed that the observed hydrological conditions were realistically represented by the VIC hydrological model for most river basins. The average daily discharges from the five GCM and its respective uncertainty were taken as an input for the geochemical model.

The input data handling and modelling in the present study follow the workflow summarised in Extended Data Fig. 2. First, a subset of the 300 largest river basins covering $\sim 70 \%$ of the global land area was selected from the HydroBASINS dataset ${ }^{49}$, including only exoreic river basins (Extended Data Fig. 3 ). The catchment area selected was derived from the HydroBASINS dataset. Second, the outlet points of river basins from the simulated river discharge VIC database were selected manually by exploring the time series for each sampling location and the surrounding points $\left( \pm 0.5^{\circ}\right)$ to choose the correct outlet. When a catchment presented several outlets (especially for endorheic catchments draining to a lake or inner sea), all of them were considered, and their discharge were added to account for all water flowing out of the drained area. Deconvolution of the daily discharge signal for each outlet is applied to distinguish between the surface runoff from the soil and groundwater flow. Third, draining area characteristics are summarised for each river basin by considering the relative abundance of lithological classes contained in the Global Lithological Map ${ }^{50}$ (GLIM), the soil classes as defined by the Harmonized World Soil Database ${ }^{51}$ (HWSD), and the climatic zones present according to the KöppenGeiger classification presented by Beck et al. $^{35}$. The modelling approach consists of two models in cascade; the flux of ions derived from the chemical weathering of rocks is computed using the ICWR ${ }^{17}$ model at a daily time step for each river basin under each discharge time series. Then, the Major Element Geochemical Approach ${ }^{37}$ (MEGA) model uses these loadings to estimate the $\mathrm{CO}_{2}$ consumed through chemical weathering.

From this set-up, a daily time series of major ion river fluxes and $\mathrm{CO}_{2}$ consumption through chemical weathering from the 300 largest river basins were obtained from 1965 to 2100 . Two periods are established to estimate the potential effect of hydrological shifts on weathering $\mathrm{CO}_{2}$ consumption: the Historical (October 1969-September 1999) and the ECP (October 2069-September 2099). A comparison between the two periods is also accomplished. Daily discharge time series have been taken from all these scenario-model combinations while temporal aggregation is performed after applying the ICWR and MEGA models.

The stream discharge time series have been deconvoluted to separate the influence of the surface runoff from the baseflow and interflow discharges. Such deconvolution is performed following the digital filter shown in Eq. (1), as proposed by Eckhardt ${ }^{52}$. In the present study, only interflow and baseflow are considered significantly transporting ions, while surface runoff is the principal agent for dilution. A digital filter based on the slopes of the increasing and decreasing parts of the hydrograph was selected. It is sensitive to changes in the amount of water and seasonality and flood events. Nonetheless, this is a source of uncertainty as the infiltration process depends on catchment-to-catchment properties, while this equation assumes linearity between the groundwater outflow (baseflow) and its storage $e^{52}$. 


$$
\mathrm{b}(\mathrm{t})=\frac{\left(1-\mathrm{BFI}_{\mathrm{mx}}\right) \cdot \mathrm{a} \cdot \mathrm{b}(\mathrm{t}-1)+(1-\mathrm{a}) \cdot \mathrm{BFI}_{\mathrm{mx}} \cdot \mathrm{Q}(\mathrm{t})}{1-\mathrm{a} \cdot \mathrm{BFI}_{\mathrm{mx}}}, \text { for } \mathrm{b}(\mathrm{t})<\mathrm{Q}(\mathrm{t})
$$

where $b(t)$ is the baseflow time series, $B F I_{m x}$ represents the long-term ratio of baseflow to total streamflow, $a$ is the filter parameter, and $Q(t)$ is the total discharge. When $b(t)>Q(t)$, then $b(t)$ is replaced by $Q(t)$. The parameters that were selected for the separation were $B F I_{m x}=0.8$ and $a=0.95$ (as recommended by Xie et al. ${ }^{53}$ ). These parameters were kept constant in all catchments, which also became a source of uncertainty.

The ICWR model is an empirical model developed to estimate major ion riverine fluxes released by chemical weathering of rocks at the global scale, based on Eq. (2). It has been validated at the global scale under static conditions ${ }^{17}$ and at the local scale under dynamic evolution ${ }^{41}$. Computing it requires a description of the draining area of each river basin in terms of soil cover and lithological distribution. The parameters of the equation take into account the concentration for each ion $x$ drained from a lithological class $i$. The ICWR model parameters were calibrated after an atmospheric input correction. Thus, the loadings computed from this equation only relate to the chemical weathering process, which is needed as an input for the MEGA model.

$$
\mathrm{F}_{\mathrm{x}}(\mathrm{t})=\mathrm{b}(\mathrm{t}) \cdot \mathrm{f}_{\mathrm{sx}} \cdot \sum\left(\mathrm{L}_{\mathrm{i}} \cdot \mathrm{C}_{\mathrm{ix}}\right)
$$

where $F_{x}$ represents the specific flux of ion $x$ in $\mathrm{mol} \mathrm{km}^{-2}$ year ${ }^{-1}, b$ represents the baseflow and interflow obtained from the deconvolution of the total discharge signal, $f_{s x}$ is a factor considering the soil shielding effect on CW (adim), $L_{i}$ is the relative abundance of a lithological class $i$ in terms of the total area of the drainage basin (expressed in the $0-1$ range), and $C_{i x}$ is the calibrated parameter that represents the concentration of the ion $x$ draining from the lithological class (expressed in $\mathrm{mol} \mathrm{L}^{-1}$ ). This equation is applied to the time series of the deconvoluted discharge, including the baseflow and interflow.

The MEGA model is based on the mass balance shown in Extended Data Fig. $4^{37}$. The input data are the riverine molar loadings of each major ion, after the atmospheric input correction. We assume that anthropogenic influence is not captured in the measurements of major ion concentrations. $R_{p y r}$ and $R_{\text {sil }}$ molar ratios for each catchment account for the $\mathrm{Ca}^{2+}+\mathrm{Mg}^{2+}$ loads coming from the weathering of silicate rocks and the $\mathrm{SO}_{4}{ }^{2-}$ originating from pyrite oxidation, respectively. The results from this model relate to the $\mathrm{CO}_{2}$ consumed by the CW of rocks.

Considering the river loadings of all major ions, the $\mathrm{CO}_{2}$ consumed is computed as follows: first, the atmospheric deposition (wet and dry) must be removed from these loads, remaining the molar fluxes derived from CW. All $\mathrm{Cl}^{-}$is associated with the dissolution of halite $(\mathrm{NaCl})$, though the remaining $\mathrm{Na}^{+}$is associated with $\mathrm{Na}-$ silicates. If the $\mathrm{Cl}^{-}>\mathrm{Na}^{+}$, the remaining $\mathrm{Cl}^{-}$is linked to the dissolution of sylvite $(\mathrm{KCl})$. Evaporites do not uptake $\mathrm{CO}_{2}$ when dissolving, while $\mathrm{Na}^{+}$and $\mathrm{K}^{-}$silicate rocks (e.g. albite $\mathrm{NaAl}_{3} \mathrm{O}_{8}$ and orthoses $\mathrm{KAlSi}_{3} \mathrm{O}_{8}$ ) require 1 mol $\mathrm{CO}_{2}$ for each ion mol released to water. Then, using $R_{p y r}$, it is possible to discriminate the $\mathrm{SO}_{4}{ }^{2-}$ load released respectively by gypsum $\left(\mathrm{CaSO}_{4}\right)$ dissolution and pyrite $\left(\mathrm{FeS}_{2}\right)$ oxidation. Gypsum does not consume $\mathrm{CO}_{2}$ during dissolution, while pyrite releases $2 \mathrm{~mol} \mathrm{CO}_{2}$ for each $\mathrm{SO}_{4}{ }^{2-}$ ion released. Later, the $C_{b}$ (molar flux of $\mathrm{Ca}^{2+}$ and $\mathrm{Mg}^{2+}$ released by carbonates dissolution) is computed using $R_{\text {sil }}$ to account for the quantity of $\mathrm{Ca}^{2+} \mathrm{and}^{\mathrm{Mg}^{2+}}$ derived from the weathering of the carbonates; a $60 \%$ of $\mathrm{Ca}^{2+}$ is linked to calcite $\left(\mathrm{CaCO}_{3}\right)$ dissolution while the remaining $40 \%$ is released by dolomite $\left(\mathrm{CaMgCO}_{3}\right)$ dissolution. The dissolution of calcite and dolomite also takes up to $1 \mathrm{~mol}$ of $\mathrm{CO}_{2}$. The remaining $\mathrm{Ca}^{2+}$ and $\mathrm{Mg}^{2+}$ fluxes are linked to silicates that consume $2 \mathrm{~mol} \mathrm{CO}_{2}$. A further description of the model calculation is found in Amiotte-Suchet ${ }^{54}$, Amiotte Suchet and Probst ${ }^{37}$ and Donnini et al. ${ }^{32}$. The $R_{p y r}$ and $R_{\text {sil }}$ values used in the present study are compiled in the Extended Data Table 1.

Two 30-year periods are considered in the present study: a Historical (1969-1999) and a ECP (2069-2099), both computed at the daily time scale. The potential impacts derived from climate change are computed by quantifying the relative difference in the ECP period to the Historical period, following Eq. (3). Where $\triangle \mathrm{CO}_{2}$ denotes the relative change for each basin (expressed in \%), and $\mathrm{L}_{\mathrm{CO} 2}$ represents the mean amount of $\mathrm{CO}_{2} \mathrm{Con}_{-}$ sumed through CW of rocks during the ECP and Historical period, expressed in $\mathrm{Mg} \mathrm{C}$ year ${ }^{-1}$. This result analysis is divided into two steps: at the annual scale, where $L_{\mathrm{CO} 2}$ is the mean annual amount of $\mathrm{CO}_{2}$ consumed in each period; and at the season scale, where $L_{\mathrm{CO} 2}$ symbolises the mean amount of $\mathrm{CO}_{2}$ consumed during all the springs, summers, autumns, and winters of each period.

$$
\Delta \mathrm{CO}_{2}(\%)=\frac{\left(\mathrm{L}_{\mathrm{CO}_{2}}^{\mathrm{ECP}}-\mathrm{L}_{\mathrm{CO}}^{\text {Historical }}\right)}{\mathrm{L}_{\mathrm{CO}_{2}}^{\text {Historical }}} \cdot 100
$$

\section{Data availability}

The data that support the findings of this study are available from the corresponding author upon reasonable request.

Received: 9 June 2021; Accepted: 18 November 2021

Published online: 08 December 2021

\section{References}

1. Calabrese, S., Parolari, A. J. \& Porporato, A. Hydrologic transport of dissolved inorganic carbon and its control on chemical weathering. J. Geophys. Res. Earth Surf. 122, 2016-2032. https://doi.org/10.1002/2017JF004346 (2017).

2. AmiotteSuchet, P. \& Probst, J. L. Modelling of atmospheric $\mathrm{CO} 2$ consumption by chemical weathering of rocks: Application to the Garonne, Congo and Amazon basins. Chem. Geol. 107, 205-210. https://doi.org/10.1016/0009-2541(93)90174-H (1993). 
3. Amiotte Suchet, P., Probst, J. L. \& Ludwig, W. Worldwide distribution of continental rock lithology: Implications for the atmospheric/soil CO2 uptake by continental weathering and alkalinity river transport to the oceans. Global Biogeochem. Cycles. https:// doi.org/10.1029/2002GB001891 (2003).

4. Bhatt, M. P., Hartmann, J. \& Acevedo, M. F. Seasonal variations of biogeochemical matter export along the Langtang-Narayani river system in central Himalaya. Geochim. Cosmochim. Acta 238, 208-234. https://doi.org/10.1016/j.gca.2018.06.033 (2018).

5. Dupré, B. et al. Rivers, chemical weathering and Earth's climate. C.R. Geosci. 335, 1141-1160. https://doi.org/10.1016/j.crte.2003. 09.015 (2003).

6. Gaillardet, J., Dupré, B., Louvat, P. \& Allègre, C. J. Global silicate weathering and $\mathrm{CO} 2$ consumption rates deduced from the chemistry of large rivers. Chem. Geol. 159, 3-30. https://doi.org/10.1016/S0009-2541(99)00031-5 (1999).

7. Hartmann, J., Jansen, N., Dürr, H. H., Kempe, S. \& Köhler, P. Global CO2-consumption by chemical weathering: What is the contribution of highly active weathering regions?. Global Planet. Change 69, 185-194. https://doi.org/10.1016/j.gloplacha.2009. 07.007 (2009).

8. Probst, J. L., Ludwig, W. \& AmiotteSuchet, P. Global modeling of $\mathrm{CO} 2$ uptake by continental erosion and of carbon river transport to the oceans/Modélisation à léchelle globale des flux de $\mathrm{CO} 2$ consommé par lérosion continentale et des transports fluviaux de carbone vers les océans. sgeol 50, 131-156. https://doi.org/10.3406/sgeol.1997.1950 (1997).

9. Probst, J. L., Mortatti, J. \& Tardy, Y. Carbon river fluxes and weathering $\mathrm{CO} 2$ consumption in the Congo and Amazon river basins. Appl. Geochem. 9, 1-13. https://doi.org/10.1016/0883-2927(94)90047-7 (1994).

10. Dessert, C., Dupré, B., Gaillardet, J., François, L. M. \& Allègre, C. J. Basalt weathering laws and the impact of basalt weathering on the global carbon cycle. Chem. Geol. 202, 257-273. https://doi.org/10.1016/j.chemgeo.2002.10.001 (2003).

11. Oliva, P., Villa, I. M. \& Dupré, B. Chemical weathering in granitic environments. Chem. Geol. 202, 225-256. https://doi.org/10. 1016/j.chemgeo.2002.08.001 (2003).

12. Ciais, P. et al. Carbon and other biogeochemical cycles. in Climate Change 2013: The Physical Science Basis. Contribution of Working Group I to the Fifth Assessment Report of the Intergovernmental Panel on Climate Change, edited by T. F. Stocker, et al. (Cambridge, 2013).

13. Liu, Z., Dreybrodt, W. \& Wang, H. A new direction in effective accounting for the atmospheric CO2 budget: Considering the combined action of carbonate dissolution, the global water cycle and photosynthetic uptake of DIC by aquatic organisms. Earth Sci. Rev. 99, 162-172. https://doi.org/10.1016/j.earscirev.2010.03.001 (2010).

14. Beaulieu, E., Goddéris, Y., Donnadieu, Y., Labat, D. \& Roelandt, C. High sensitivity of the continental-weathering carbon dioxide sink to future climate change. Nat. Clim. Change 2, 346-349. https://doi.org/10.1038/nclimate1419 (2012).

15. Conant, R. T. et al. Temperature and soil organic matter decomposition rates - Synthesis of current knowledge and a way forward. Glob. Change Biol. 17, 3392-3404. https://doi.org/10.1111/j.1365-2486.2011.02496.x (2011).

16. Gaillardet, J., Calmels, D., Romero-Mujalli, G., Zakharova, E. \& Hartmann, J. Global climate control on carbonate weathering intensity. Chem. Geol. 527, 118762. https://doi.org/10.1016/j.chemgeo.2018.05.009 (2019).

17. Lechuga-Crespo, J. L. et al. A model to evaluate chemical weathering from riverine transports of dissolved major elements at global scale. Global Planet. Change. https://doi.org/10.1016/j.gloplacha.2020.103226 (2020).

18. Roelandt, C., Goddéris, Y., Bonnet, M.-P. \& Sondag, F. Coupled modeling of biospheric and chemical weathering processes at the continental scale. Global Biogeochem. Cycles. https://doi.org/10.1029/2008GB003420 (2010).

19. Bao, C., Li, L., Shi, Y. \& Duffy, C. Understanding watershed hydrogeochemistry: 1. Development of RT-Flux-PIHM. Water Resour. Res. 53, 2328-2345. https://doi.org/10.1002/2016WR018934 (2017).

20. Li, L. et al. Expanding the role of reactive transport models in critical zone processes. Earth Sci. Rev. 165, 280-301. https://doi. org/10.1016/j.earscirev.2016.09.001 (2017).

21. Amiotte Suchet, P. \& Probst, J. L. A global model for present-day atmospheric/soil CO2 consumption by chemical erosion of continental rocks (GEM-CO2). Tellus B 47B, 273-280. https://doi.org/10.1034/j.1600-0889.47.issue1.23.x (1995).

22. Aumont, O. et al. Riverine-driven interhemispheric transport of carbon. Global Biogeochem. Cycles 15, 393-405. https://doi.org/ 10.1029/1999GB001238 (2001).

23. McClain, M. et al. Biogeochemical hot spots and hot moments at the interface of terrestrial and aquatic ecosystems. Ecosystems 6, 301-312. https://doi.org/10.1007/s10021-003-0161-9 (2003).

24. Berner, R. A., Lasaga, A. C. \& Garrels, R. M. The carbonate-silicate geochemical cycle and its effect on atmospheric carbon dioxide over the past 100 million years. Am. J. Sci. 283, 641-683. https://doi.org/10.2475/ajs.283.7.641 (1983).

25. Meybeck, M. Global chemical weathering of surficial rocks estimated from river dissolved loads. Am. J. Sci. 287, 401-428. https:// doi.org/10.2475/ajs.287.5.401 (1987).

26. Munhoven, G. Glacial-interglacial changes of continental weathering: Estimates of the related $\mathrm{CO} 2$ and $\mathrm{HCO} 3$ flux variations and their uncertainties. Global Planet. Change 33, 155-176. https://doi.org/10.1016/S0921-8181(02)00068-1 (2002).

27. Probst, J. L. Géochimie et hydrologie de lérosion continentale. Mécanismes, bilan global actuel et fluctuations au cours des 500 derniers millions d'années. (Université Louis-Pasteur, 1992).

28. van Vuuren, D. P. et al. The representative concentration pathways: An overview. Clim. Change 109, 5-31. https://doi.org/10.1007/ s10584-011-0148-z (2011).

29. Moquet, J.-S. et al. Amazon River dissolved load: Temporal dynamics and annual budget from the Andes to the ocean. Environ. Sci. Pollut. Res. Int. 23, 11405-11429. https://doi.org/10.1007/s11356-015-5503-6 (2016).

30. Mortatti, J. \& Probst, J.-L. Silicate rock weathering and atmospheric/soil CO2 uptake in the Amazon basin estimated from river water geochemistry: Seasonal and spatial variations. Chem. Geol. 197, 177-196. https://doi.org/10.1016/S0009-2541(02)00349-2 (2003).

31. Boeglin, J. L. \& Probst, J. L. Physical and chemical weathering rates and $\mathrm{CO} 2$ consumption in a tropical lateritic environment: The upper Niger basin. Chem. Geol. https://doi.org/10.1016/S0009-2541(98)00025-4 (1998).

32. Donnini, M. et al. Chemical weathering and consumption of atmospheric carbon dioxide in the Alpine region. Global Planet. Change 136, 65-81. https://doi.org/10.1016/j.gloplacha.2015.10.017 (2016).

33. Moosdorf, N., Hartmann, J., Lauerwald, R., Hagedorn, B. \& Kempe, S. Atmospheric CO2 consumption by chemical weathering in North America. Geochim. Cosmochim. Acta 75, 7829-7854. https://doi.org/10.1016/j.gca.2011.10.007 (2011).

34. van Vliet, M. T. H. et al. Global river discharge and water temperature under climate change. Global Environ. Change 23, 450-464. https://doi.org/10.1016/j.gloenvcha.2012.11.002 (2013).

35. Beck, H. E. et al. Present and future Köppen-Geiger climate classification maps at 1-km resolution. Sci. Data 5, 180214. https:// doi.org/10.1038/sdata.2018.214 (2018).

36. van Vliet, M. T. H., Wiberg, D., Leduc, S. \& Riahi, K. Power-generation system vulnerability and adaptation to changes in climate and water resources. Nat. Clim. Change 6, 375-380. https://doi.org/10.1038/NCLIMATE2903 (2016).

37. Amiotte Suchet, P. \& Probst, J. L. Origines du carbone inorganique dissous dans les eaux de la Garonne. Variations saisonnières et interannuelles/Sources of dissolved inorganic carbon in the Garonne river water. Seasonal and inter annual variations. sgeol 49, 101-126. https://doi.org/10.3406/sgeol.1996.1938 (1996).

38. Streletskiy, D., Anisimov, O. \& Vasiliev, A. Permafrost Degrad. https://doi.org/10.1016/B978-0-12-394849-6.00010-X (2015).

39. Millot, R., Gaillardet, J., Dupré, B. \& Allègre, C. J. The global control of silicate weathering rates and the coupling with physical erosion: New insights from rivers of the Canadian Shield. Earth Planet. Sci. Lett. 196, 83-98. https://doi.org/10.1016/S0012-821X(01) 00599-4 (2002). 
40. Beaulieu, E. et al. Impact of atmospheric CO2 levels on continental silicate weathering. Geochem. Geophys. Geosyst. https://doi. org/10.1029/2010GC003078 (2010).

41. Lechuga-Crespo, J. L., Sauvage, S., Ruiz-Romera, E., George, C. \& Sánchez-Pérez, J. M. SWATLitho: A hydrogeochemical model to estimate daily geochemical loads at the catchment scale. Environ. Model. Softw. 135, 104893. https://doi.org/10.1016/j.envsoft. 2020.104893 (2021).

42. Delworth, T. L. et al. GFDL's CM2 global coupled climate models. Part I: Formulation and simulation characteristics. Am. Meteorol. Soc. 19, 643-674. https://doi.org/10.1175/JCLI3629.1 (2006).

43. Donner, L. J. et al. The dynamical core, physical parameterizations, and basic simulation characteristics of the atmospheric component AM3 of the GFDL global coupled model CM3. J. Clim. 24, 3484-3519. https://doi.org/10.1175/2011JCLI3955.1 (2011).

44. Collins, W. J. et al. Development and evaluation of an Earth-system model - HadGEM2. Geosci. Model Dev. Discuss. 4, 997-1062. https://doi.org/10.5194/gmdd-4-997-2011 (2011).

45. Martin, G. M. et al. The HadGEM2 family of met office unified model climate configurations. Geosci. Model Dev. 4, 723-757. https://doi.org/10.5194/gmd-4-723-2011 (2011).

46. Dufresne, J.-L. et al. Climate change projections using the IPSL-CM5 Earth System Model: from CMIP3 to CMIP5. Clim. Dyn. 40, 2123-2165. https://doi.org/10.1007/s00382-012-1636-1 (2013).

47. Watanabe, S. et al. MIROC-ESM 2010: Model description and basic results of CMIP5-20c3m experiments. Geosci. Model Dev. 4, 845-872. https://doi.org/10.5194/gmd-4-845-2011 (2011).

48. Iversen, T. et al. The Norwegian earth system model, NorESM1-M-Part 2: Climate response and scenario projections. Geosci. Model Dev. 6, 389-415 (2013).

49. Lehner, B. \& Grill, G. Global river hydrography and network routing: Baseline data and new approaches to study the world's large river systems. Hydrol. Process. 27, 2171-2186. https://www.hydrosheds.org (2013).

50. Hartmann, J. \& Moosdorf, N. The new global lithological map database GLiM: A representation of rock properties at the Earth surface. Geochem. Geophys. Geosyst. https://doi.org/10.1029/2012GC004370 (2012).

51. FAO, IIASA, ISRIC, ISS-CAS \& JRC. Harmonized World Soil Database (version 1.2). (FAO, 2012).

52. Eckhardt, K. How to construct recursive digital filters for baseflow separation. Hydrol. Process. 19, 507-515. https://doi.org/10. 1002/hyp.5675 (2005).

53. Xie, J. et al. Evaluation of typical methods for baseflow separation in the contiguous United States. J. Hydrol. 583, 124628. https:// doi.org/10.1016/j.jhydrol.2020.124628 (2020).

54. Amiotte Suchet, P. Cycle du Carbone, Érosion Chimique des Continents et Transferts vers les Océans. (Université Louis-Pasteur, 1995).

\section{Acknowledgements}

Authors wish to thank the Basque Government (Hydro-Environmental Processes Consolidated Group, IT102916), the University of the Basque Country (UPV/EHU, UFI11/26), the Institut National Polytechnique de Toulouse (INPT) and the Centre National de la Recherche Scientifique (CNRS) for supporting this research.

\section{Author contributions}

J.L.L.C. contributed by developing the methodology, obtaining the results, and writing the first draft; S.S., E.R.R. and J.M.S.P. assisted in defining the idea; M.T.H.v.V., J.L.P., and C.F. discussed the results and contributed to the writing. All authors helped in refining the manuscript.

\section{Competing interests}

The authors declare no competing interests.

\section{Additional information}

Supplementary Information The online version contains supplementary material available at https://doi.org/ 10.1038/s41598-021-02891-y.

Correspondence and requests for materials should be addressed to J.M.S.-P.

Reprints and permissions information is available at www.nature.com/reprints.

Publisher's note Springer Nature remains neutral with regard to jurisdictional claims in published maps and institutional affiliations.

(c) (i) Open Access This article is licensed under a Creative Commons Attribution 4.0 International License, which permits use, sharing, adaptation, distribution and reproduction in any medium or format, as long as you give appropriate credit to the original author(s) and the source, provide a link to the Creative Commons licence, and indicate if changes were made. The images or other third party material in this article are included in the article's Creative Commons licence, unless indicated otherwise in a credit line to the material. If material is not included in the article's Creative Commons licence and your intended use is not permitted by statutory regulation or exceeds the permitted use, you will need to obtain permission directly from the copyright holder. To view a copy of this licence, visit http://creativecommons.org/licenses/by/4.0/.

(C) The Author(s) 2021 